\title{
Detection of hepatitis C virus (HCV) among health care providers in an Egyptian university hospital: different diagnostic modalities
}

\author{
This article was published in the following Dove Press journal: \\ Infection and Drug Resistance \\ 17 October 2017 \\ Number of times this article has been viewed
}

\author{
Rehab H El-Sokkary' \\ Rehab M Elsaid Tash' \\ Takwa E Meawed' \\ Omnia S El Seifi² \\ Eman M Mortada ${ }^{2}$ \\ 'Medical Microbiology and \\ Immunology Department, \\ ${ }^{2}$ Community, Environmental and \\ Occupational Medicine Department, \\ Faculty of Medicine, Zagazig \\ University, Zagazig, Egypt
}

Background: Hepatitis $\mathrm{C}$ virus $(\mathrm{HCV})$ infection has received much attention and is placed at the core of the infection control agenda. It is considered as a major public health problem in Egypt, where the highest prevalence of HCV exists. The great risk of exposure to infection of health care providers (HCPs) has highlighted the urgent need for implementing an infection control program. Objective: The purpose of this study was to detect the prevalence of HCV infection among HCPs in Zagazig University Hospitals and to assess the performance of different diagnostic modalities. Methodology: Blood, polymerase chain reaction (PCR), enzyme-linked immunosorbent assay (ELISA), and saliva tests were performed in enrolled HCPs.

Results: This study compared HCV diagnosis Hepanostika HCV Ultra ELISA as a screening test and PCR as gold standard test, which resulted in $40.6 \%$ positive results by ELISA compared to $34.8 \%$ by PCR $(p<0.0001)$, while OraQuick HCV rapid antibody compared to PCR shows that $37.7 \%$ of the participants were positive by OraQuick HCV rapid antibody test. Application of standard precautions while dealing with blood has negative significant correlation with HCV infection $\left(r_{s}=-0.265, p=0.03\right)$.

Conclusion: HCPs at Zagazig University Hospitals are at high risk for HCV infection. Lack of compliance and awareness of prevention and control of the infection are associated cofactors. Serum HCV-Ab detection by Hepanostika HCV Ultra ELISA and OraQuick HCV rapid antibody test are sensitive and specific serologic assays for diagnosis with correspondent results to that obtained by quantitative real-time PCR.

Keywords: HCV, ROC curve, OraQuick HCV, infection control

\section{Introduction}

Hepatitis $\mathrm{C}$ virus (HCV) is a global health threat, with Egypt having the highest prevalence worldwide. ${ }^{1}$ Most HCV transmission opportunities in Egypt are related to medical injections and procedures. ${ }^{2}$ Health care workers (HCWs) represent a highrisk population for sharps injuries, needles, and scalpels during the execution of their health care duties. In addition, HCW's mucosa may be exposed to droplets or splashes of blood, saliva, and urine. These occupational exposure accidents carry an estimated risk of $2 \% \mathrm{HCV}$ transmission. ${ }^{3,4}$ World Health Organization (WHO) estimates that each year more than 3 million health workers hurt themselves with an object/edge definitely contaminated with at least one HIV ( 170,000 exposures), hepatitis B $(\sim 2,000,000$ exposures), and hepatitis C ( $\sim 900,000$ exposures $).{ }^{5}$ As there is no available vaccination for HCV up till now, the use of standard precautions coupled with strict adherence to post-exposure prophylactic measures to HCV are the available measures for prevention.
Correspondence: Eman M Mortada Community, Environmental and Occupational Medicine Department Faculty of Medicine, Zagazig University, Egypt-Al-Sharqia Governorate,

Zagazig 44519, Egypt

$\mathrm{Tel}+201096865168$

Email info_medicine@zu.edu.eg 
Yet, lack of compliance hampered HCW response. ${ }^{6}$ Personnel with HCV antibody-positive and HCV RNA-positive status by polymerase chain reaction (PCR) or those in whom $\mathrm{HCV}$ RNA PCR status is yet to be determined should be excluded from exposure prone procedures. ${ }^{7}$

Different methods assist in HCV diagnosis including third-generation enzyme-linked immunosorbent assay (ELISA) for the detection of anti-HCV antibodies. ${ }^{8}$ It includes multiple recombinant $\mathrm{HCV}$ antigens with subsequent reduction of the window period and improvement in the detection of patients exposed to HCV. Several points of care testing have been developed to detect HCV-specific antibodies with a relatively high sensitivity and specificity. The only test currently approved by the Food and Drug Administration is the OraQuick HCV rapid assay (OraSure Technologies Inc., Bethlehem, PA, USA). This test detects HCV antibodies in fingerstick and venipuncture whole blood, serum, plasma, or oral fluid specimens by an indirect lateral flow immunoassay. Core, NS3, and NS4 antigens are immobilized on a nitrocellulose membrane, and the results are directly visualized using colloidal gold labeled with protein A. Molecular assays to detect the HCV genome are used for the diagnosis of active $\mathrm{HCV}$ infection in patients with a positive antibody test, an early diagnosis of acute HCV infection, as the HCV-RNA can be detected before specific antibodies become detectable (within 1-3 weeks after exposure). Moreover, the diagnosis of a chronic $\mathrm{HCV}$ infection is confirmed by the presence of both HCV antibodies (with the exception of severely immune-suppressed patients) and HCV RNA over 6 months. ${ }^{9}$
As accurate diagnosis of $\mathrm{HCV}$ is a corner stone in control of disease spread, the current work was conducted to detect the prevalence of $\mathrm{HCV}$ occupational infection among health care providers in Zagazig University Hospitals and to assess the performance of the different diagnostic modalities.

\section{Subjects and methods Study design and settings}

A cross-sectional study was conducted in Zagazig University hospitals, in the eastern province of Egypt with more than 2000 beds. It took place over a period of 18 months. Infection control unit-Zagazig University hospitals has a reporting system for needle stick and sharps injuries (NSSIs).

\section{Study participants}

Sixty-nine cases were enrolled for the study. They were selected as shown in Figure 1. Over 18 months, a total of 104 NSSIs reports were delivered to the unit. After excluding 28 cases, 12 cases were positive for $\mathrm{HCV}$ at the time of reporting, 10 cases had a history of other risk factors of $\mathrm{HCV}$ infection (eg, previous blood transfusion, liver disease, etc), and 6 cases had no index patients. Seventy-six HCWs were interviewed after explaining the study protocol. Three refused to participate in the study, four agreed to participate in saliva test but refused to give blood sample for the other two tests. Sixty-nine individuals accepted to participate in the study by the 3 diagnostic modalities.

The selection and consent of participants were done at the time of reporting of sharp injury. Each filled a structured

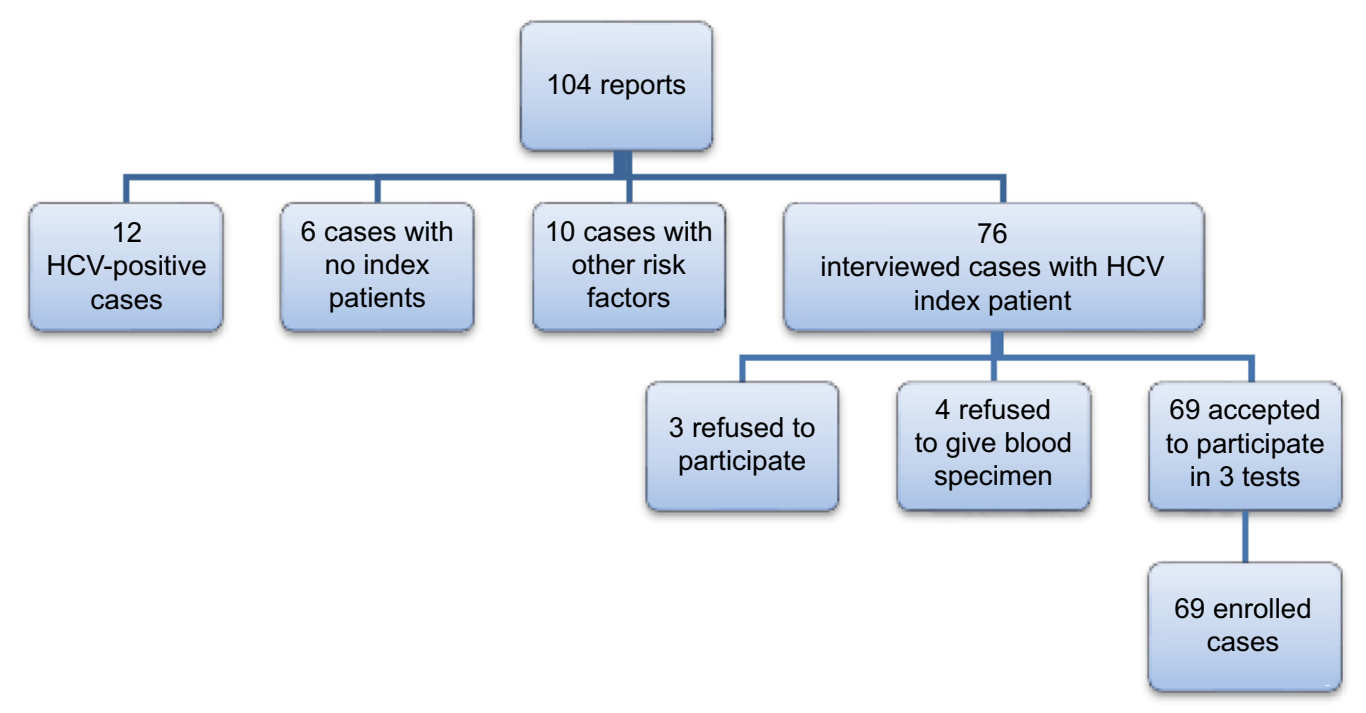

Figure I Frame work of the participants in the study during study period. Abbreviation: $\mathrm{HCV}$, hepatitis $\mathrm{C}$ virus. 
questionnaire; eight weeks later, blood was sampled from participants for PCR and ELISA anti HCV Ab detection, and saliva was collected for screening of $\mathrm{HCV} \mathrm{Ab}$.

\section{Tools used for data collection}

a- A structured questionnaire was designed consisting of several parts. The first part included questions about general characters of the participants such as gender, age, residence, profession, smoking, allergy to medications, presence of chronic diseases, and history of HBV vaccine. The second part of the questionnaire asked participants about their history, current incident, and the circumstances of the most sharp injury that presedispose to HCV infection (eg, direct contact with blood, application of standard precautions on dealing with blood, using protective personal equipments, frequency of attending dental clinics, and presece of case of $\mathrm{HCV}$ within family).

b- Microbiological investigations: The following three tests for $\mathrm{HCV}$ were performed for each of the 69 participants: $\mathrm{HCV}$-antibody detection by saliva test, HCV-antibody detection by ELISA, and HCV RNA detection by reverse transcription (RT) real-time PCR. Oral cavity was swabbed for saliva, and the test was performed immediately. For the other two tests, blood sample was aseptically collected; a volume of $2 \mathrm{~mL}$ serum and $2 \mathrm{~mL}$ plasma were separated by centrifugation. They were frozen to $-80^{\circ} \mathrm{C}$ within 2 hours of collection until use.

a. Detection of $\mathrm{HCV}-\mathrm{Ab}$ was carried out in serum samples using a commercially available 3rd generation enzyme immunoassay (Hepanostika HCV Ultra; UBI Diagnostics, Beijing, China). As stated in manufacturer's guide, initially, samples were tested in duplicate. Samples which did not react in any of the tests were considered non-reactive for $\mathrm{HCV}$ antibodies. Reactive samples in one or two tests were considered as positive for $\mathrm{HCV}$ antibodies.

b. Saliva test for anti-HCV antibody testing: An indirect lateral flow qualitative immunoassay was used (OraQuick HCV rapid antibody test; OraSure). According to the manufacturer's instructions, swiping gums with the collection pad of the device was performed. A reddish-purple line develops within 20 minutes in the presence of $\mathrm{HCV}$-specific antibodies. ${ }^{9}$

c. RT real-time PCR for quantitative $\mathrm{HCV}$ RNA detection:

i. RNA extraction: RNA was extracted from $140 \mu \mathrm{L}$ of plasma using QIAamp UltraSense virus kit (Qiagen, NV, Venlo, the Netherlands) according to the manufacturer's protocol. The extracted RNA was eluted in elution buffer and used as the template for the quantitative RNA PCR.

ii Taqman real-time PCR was implemented using HCV quantification kit with a lower limit of sensitivity of $50 \mathrm{IU} / \mathrm{mL}$ (Amplicor 2.0; Roche Diagnostics, Meylan, France). Procedures were done according to the manufacturer's instructions using Rotor gene 2000/3000 real-time PCR machine (Applied Biosystems Sequence Detector 7500 machine; Thermo Fisher Scientific, Waltham, MA, USA). The threshold cycle values from the clinical samples were plotted on the standard curve, and the numbers of copies were automatically calculated. For each run, positive and negative controls were included.

\section{Data management and analysis}

The data were analyzed by SPSS 19 (IBM, Armonk, NY, USA) using the suitable test based on the type of the collected data. Descriptive statistics such as frequency, percent, mean, and SD were determined. The performance of ELISA and saliva as screening tests compared to PCR as a gold standard test was assessed using the area under receiver operating characteristic (ROC) curve to define a cut-off value of model score among study participants; the sensitivity, specificity, accuracy as well as agreement using Cohen kappa test $(k)$ with cutoff points $<0.4$ was considered as poor agreement, $>0.75$ was considered as excellent agreement, and in-between as good one. Factors that correlate to the infection by HCV virus diagnosed by PCR were determined by calculating Spearman correlation coefficient $\left(r_{s}\right) . P$-value $<0.05$ was considered as statistically significant in all analyses.

\section{Ethical considerations}

Before collecting data, all the required official permissions were obtained, and the study protocol was approved by Institutional Review Board of Faculty of Medicine, Zagazig University. Participants were informed about the objectives and the importance of the study. Those who agreed to participate signed an informed consent. Also, the participants were informed that their participation is voluntary assuring the confidentiality of the collected information through anonymity of the participant, and that, study results will be used only for the purpose of research.

\section{Results}

Regarding the general characters of the study participants, their mean age was $31.8 \pm 8.06$, most of them were males 
$(52.2 \%)$, from rural areas $(71.0 \%)$, the majority of them were nurses (62.3\%), and least were laboratory technicians (1.4\%). Most of the participants were non-smokers (91.3\%); they did not have any chronic diseases $(92.8 \%)$, and $71 \%$ have history of hepatitis B virus vaccination as revealed in Table 1.

Regarding the distribution of factors that might be associated with increasing risk of $\mathrm{HCV}$ infection among participants, it was found that $(60.9 \%)$ of them had their work exposing them to direct blood contact, $87.0 \%$ of them apply standard precautions while dealing with blood, only $27.5 \%$ had direct blood contact without protection. All of them reported using personal protective equipment in work; $98.6 \%$ rarely attend to dental clinics, and the presence of $\mathrm{HCV}$ infection within the family was confirmed by $31.9 \%$ of them (Table 2).

\section{$\mathrm{HCV}$ detection methods}

Comparing $\mathrm{HCV}$ diagnosis by serum $\mathrm{HCV}-\mathrm{Ab}$ detection using Hepanostika HCV Ultra ELISA as a screening test and PCR as a gold standard test, resulting in that $40.6 \%$ of participants had positive results for HCV by ELISA compared with

Table I General characters of the health care providers

\begin{tabular}{|c|c|c|}
\hline Variables & $\begin{array}{l}N \\
(69)\end{array}$ & $\begin{array}{l}\% \\
(100.0)\end{array}$ \\
\hline \multicolumn{3}{|l|}{ Age } \\
\hline Mean age $\pm S D$, years & $31.8 \pm 8.06$ & \\
\hline \multicolumn{3}{|l|}{ Gender } \\
\hline Female & 33 & 47.8 \\
\hline Male & 36 & 52.2 \\
\hline \multicolumn{3}{|l|}{ Residency } \\
\hline Urban & 49 & 71.0 \\
\hline Rural & 20 & 29.0 \\
\hline \multicolumn{3}{|l|}{ Profession } \\
\hline Physicians & 6 & 8.7 \\
\hline Nurses & 43 & 62.3 \\
\hline Laboratory technicians & 1 & 1.4 \\
\hline Dentists & 6 & 8.7 \\
\hline Interns & 9 & 13.0 \\
\hline Students & 4 & 5.8 \\
\hline \multicolumn{3}{|l|}{ Smoking } \\
\hline Yes & 6 & 8.7 \\
\hline No & 63 & 91.3 \\
\hline \multicolumn{3}{|l|}{ Having chronic diseases } \\
\hline No & 64 & 92.8 \\
\hline Auto immune disease & 1 & 1.4 \\
\hline Hypertension & I & 1.4 \\
\hline Diabetes & 3 & 4.3 \\
\hline \multicolumn{3}{|l|}{ HBV vaccination } \\
\hline \multicolumn{3}{|l|}{ History vaccination } \\
\hline Negative & 20 & 29.0 \\
\hline Positive & 49 & 71.0 \\
\hline
\end{tabular}

Abbreviation: $\mathrm{HBV}$, hepatitis $\mathrm{B}$ virus.
$34.8 \%$ by PCR with high significant difference $(p<0.001)$, and level of agreement is good $(k=0.69)$ as shown in Table 3. Using ROC curve, the area under the curve was $86.0 \%$ giving a sensitivity of $87.5 \%$, specificity $84.4,1-$ specificity (false positive $=15.6 \%), 1-$ sensitivity (false negative $=12.5 \%$ ) with diagnostic accuracy (85.5\%) as shown in Figure 2. Similarly, on assessing the performance of OraQuick HCV rapid antibody test as a screening test compared to PCR in diagnosis of $\mathrm{HCV}$ infection shows that $37.7 \%$ of the participants were diagnosed positive by OraQuick HCV rapid antibody test compared to $34.8 \%$ by PCR with high significant difference ( $p>0.001)$ with good level of agreement $(k=0.69)$ as shown in Table 4 , and from ROC curve, the area under the curve was $(85.0 \%)(p=0.000)$ with a sensitivity of $83.33 \%$, specificity $86.67 \%, 1-$ specificity (false positive $=13.33 \%$ ), 1 -sensitivity (false negative $=16.67 \%$ ), resulting in $85.5 \%$ diagnostic accuracy as shown in Figure 3.

Regarding the relation between PCR results and predisposing factors of HCV infection among participants, Table 5 represents that, among the enlisted factors, the direct blood contact without protection was significantly positive, correlated to HCV infection as diagnosed by PCR $(p=0.02)$, whereas application of standard precautions while dealing with blood has negative significant correlation with $\mathrm{HCV}$ infection $\left(r_{s}=-0.3, p=0.03\right)$

Table 2 Distribution of factors associated with increasing risk of $\mathrm{HCV}$ infection among participants

\begin{tabular}{|c|c|c|}
\hline Variables & $\begin{array}{l}N \\
(69)\end{array}$ & $\begin{array}{l}\% \\
(100.0)\end{array}$ \\
\hline \multicolumn{3}{|c|}{ Direct blood contact in work } \\
\hline Yes & 42 & 60.9 \\
\hline No & 27 & 39.1 \\
\hline \multicolumn{3}{|c|}{ Application of standard precautions while } \\
\hline dealing with blood & 60 & 87.0 \\
\hline Yes & 9 & 13.0 \\
\hline \multicolumn{3}{|l|}{ No } \\
\hline \multicolumn{3}{|c|}{ Direct blood contact without protection } \\
\hline Yes & 19 & 27.5 \\
\hline No & 50 & 72.5 \\
\hline \multicolumn{3}{|c|}{ Always using personal protective equipment } \\
\hline Yes & 69 & 100.0 \\
\hline No & 0 & 0.0 \\
\hline \multicolumn{3}{|c|}{ Frequency of attending dental clinic } \\
\hline Rare & 68 & 98.6 \\
\hline Sometimes & I & $\mathrm{I} .4$ \\
\hline \multicolumn{3}{|c|}{ Presence of $\mathrm{HBV}$ or $\mathrm{HCV}$ infection within } \\
\hline the family & 46 & 66.7 \\
\hline No & 22 & 31.9 \\
\hline $\mathrm{HCV}$ & I & 1.4 \\
\hline HBV & & \\
\hline
\end{tabular}

Abbreviations: $\mathrm{HBV}$, hepatitis $B$ virus; $\mathrm{HCV}$, hepatitis $\mathrm{C}$ virus. 
Table 3 ELISA as a screening test compared to PCR for diagnosis of HCV infection

\begin{tabular}{lllll}
\hline Test & PCR & & Total & Cohen's kappa \\
\cline { 2 - 3 } & Positive & Negative & & \\
\hline ELISA & $21(30.4 \%)$ & $7(10.1 \%)$ & $28(40.6 \%)$ & 0.6925 \\
Positive & $3(4.3 \%)$ & $38(55.1 \%)$ & $41(59.4 \%)$ & 0.0000 \\
Negative & $24(34.8 \%)$ & $45(65.2 \%)$ & $69(100.0 \%)$ & \\
Total & & &
\end{tabular}

Note: Significance difference $p \leq 0.05$

Abbreviations: ELISA, enzyme-linked immunosorbent assay; PCR, polymerase chain reaction.

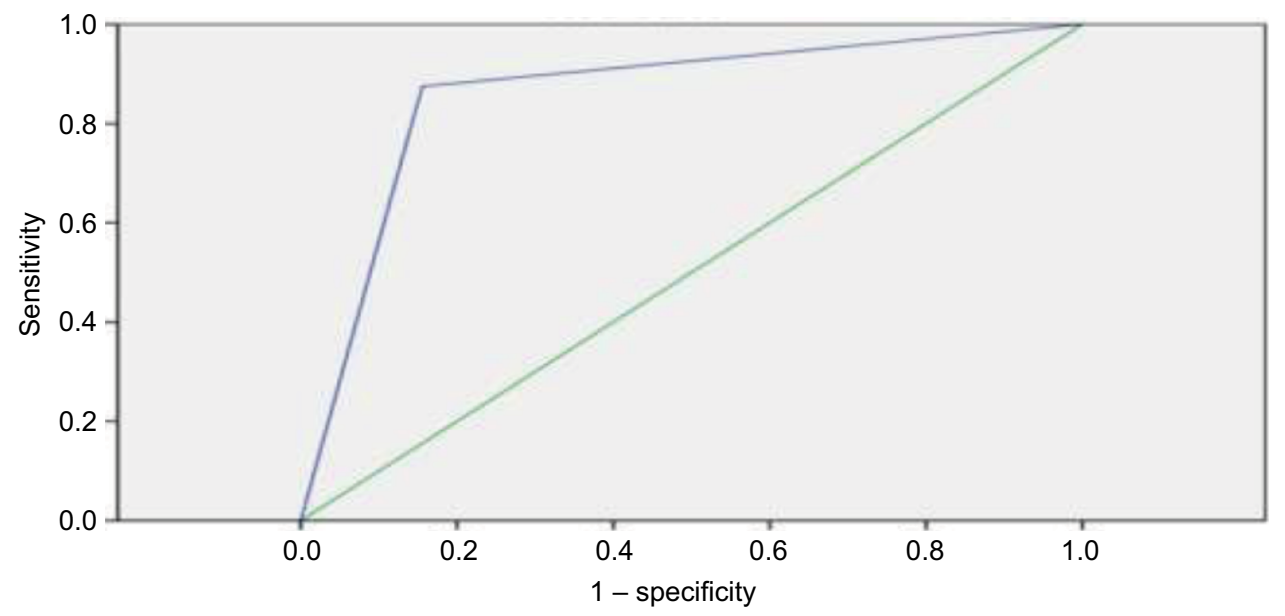

Figure 2 Receiver operating characteristic curve for ELISA to diagnose hepatitis $C$ virus infection.

Abbreviations: ELISA, enzyme-linked immunosorbent assay; ROC, receiver operating characteristic.

Table 4 OraQuick HCV rapid antibody test as a screening test compared to PCR in diagnosis of HCV infection

\begin{tabular}{|c|c|c|c|c|c|}
\hline \multirow[t]{2}{*}{ Test } & \multicolumn{2}{|l|}{ PCR } & \multirow[t]{2}{*}{ Total } & \multirow[t]{2}{*}{ Cohen's kappa } & \multirow[t]{2}{*}{$P$-value } \\
\hline & Positive & $\overline{\text { Negative }}$ & & & \\
\hline \multicolumn{6}{|c|}{ OraQuick HCV rapid antibody test } \\
\hline Positive & $20(29.0 \%)$ & $6(8.7 \%)$ & 26 (37.7\%) & 0.6866 & 0.0000 \\
\hline Negative & $4(5.8 \%)$ & 39 (56.5\%) & $43(62.3 \%)$ & & \\
\hline Total & $24(34.8 \%)$ & 45 (65.2\%) & $69(100.0 \%)$ & & \\
\hline
\end{tabular}

Note: Significance difference $p \leq 0.05$.

Abbreviations: $\mathrm{HCV}$, hepatitis $\mathrm{C}$ virus; $\mathrm{PCR}$, polymerase chain reaction.

Quantitative HCV-RNA showed different values of HCV-RNA number, $65.2 \%$ of them (45 out of 69 ) having undetectable level of HCV-RNA, while positive subjects had their viral loads ranged from 39.000 to $131.000 \mathrm{IU} / \mathrm{mL}$.

\section{Discussion}

The prevalence of anti-HCV in Egypt was 14\%, about $11,826,360$ persons infected with $\mathrm{HCV}$ in $2010 .{ }^{10} \mathrm{HCW}$ are at increased risk of contracting HCV. At the individual level, this risk has two dimensions. In the first dimension, HCWs are performing hazardous and unsafe injection delivery practices, and in the second, they seek care as a patient in a system with lax infection control regulations. At a broader level of health system operations, this is due to quality issues in health care delivery. ${ }^{11}$
Current study clarified that the prevalence of $\mathrm{HCV}$ among investigated HCW by real-time PCR was $34.8 \%$. A study carried out in 2012 among Egyptian HCWs at a national liver disease referral center detected a prevalence of hepatitis $\mathrm{C}$ virus antibody (HCV-Ab) to be $16.6 \% .^{12}$ Another study in Cairo found that, among $597 \mathrm{HCWs}$ who reported a blood exposure, the anti-HCV prevalence was $7.2 \%{ }^{13}$ Okasha et $\mathrm{al}^{6}$ found a prevalence of $8 \%$ in Ain Shams University Hospitals. El-Melligy et a ${ }^{14}$ detected HCV-Ab in $6.14 \%$ of Egyptian HCWs at Teaching Hospital being significantly higher in individuals aged $\geq 40$ years when compared with those $<40$ years. Half of those with positive HCV-Ab had HCV-RNA below the detection limit. ${ }^{14}$ Lower figure of 5.2\% of HCWs were anti HCV positive as reported by Zayet et al in 2015 in Aasuit General Surgery Department, Egypt. ${ }^{15}$ 


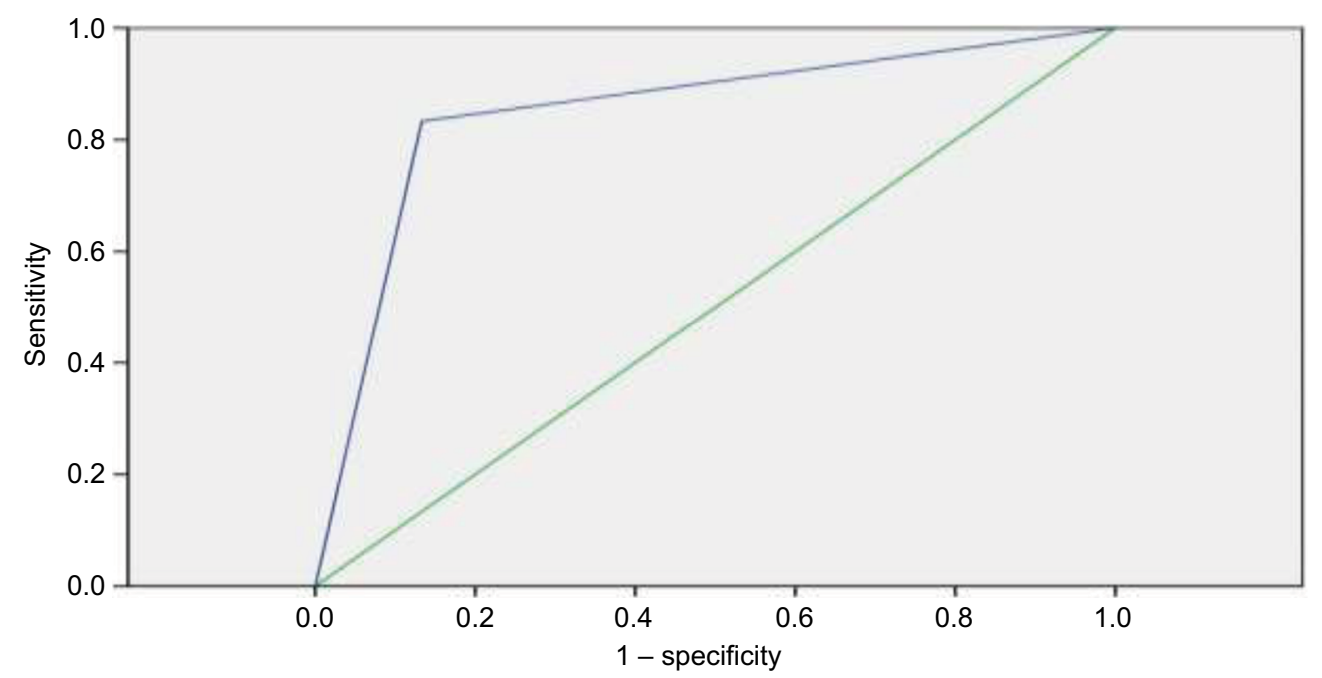

Figure 3 Receiver operating characteristic curve for OraQuick HCV rapid antibody test to diagnose HCV infection. Abbreviation: ROC, receiver operating characteristic.

Table 5 The correlation between PCR readings and factors increasing infection among participants

\begin{tabular}{lll}
\hline Variables & ${ }^{*} \boldsymbol{r}_{\boldsymbol{s}}$ & $* * \boldsymbol{P}$-value \\
\hline Direct blood contact in work & 0.100 & 0.421 \\
Application of standard precautions while & -0.265 & 0.028 \\
dealing with blood & & \\
Direct blood contact without protection & 0.027 & 0.019 \\
Frequency of attending dental clinic & 0.089 & 0.469 \\
Presence of HBV or HCV infection within the & 0.007 & 0.952 \\
family & & \\
\hline
\end{tabular}

Note: *Spearman correlation, ${ }^{* *} p<0.05$ is significant.

Abbreviations: PCR, polymerase chain reaction; HBV, hepatitis B virus; $\mathrm{HCV}$, hepatitis $C$ virus.

Eskandarani et al ${ }^{16}$ in 2014 argued that even with frequent exposure to blood and body fluids (BBF) among HCWs, the risk of HCV infection among Danish hospital staff was low represented $3.8 \%$. However, they could not rule out the possibility of transmission due to significant underreporting and disobedience to follow-up blood testing, and they proposed improving surveillance of BBF exposure. ${ }^{16}$

Although the detected prevalence is much higher than those from different studies, yet this can be explained by the high prevalence of $\mathrm{HCV}$ among the general population. In a finding reported earlier by Munier et al in 2012, the HCV prevalence among HCWs was similar to that of the general population. ${ }^{13}$ Also, this difference may be due to the number of HCWs in the facility, different work environment, training, culture, availability of resources, ${ }^{17}$ and to the implementation of infection control guidelines. ${ }^{14}$ To further understand the gap that exists between written policies and procedures and actual practice, we distributed self-administered questionnaires about factors associated with increased risk of infection. The results showed that $50 \%$ of study participants have direct contact to blood or other body fluids during their routine work, $30 \%$ of them confirmed adherence to personal protective equipment with non-compliance of the remaining majority. In like manner, different studies ${ }^{2,3,17}$ have reported suboptimal and non-uniform adherence to standard precautions by HCWs in developing countries as in developed. A large-scaled study done in West India reported that the majority $(81.5 \%)$ of the respondents experienced splashes from body fluid. ${ }^{18}$

In this study, over three-quarters of medical doctors (78\%) and two-thirds of nurses (64\%) reported having experienced NSSIs, while the incidence among medical technologists was remarkably lower (26\%). In a previous Indian study, 84 respondents reported NSSIs. The majority of the respondents (59\%) experienced low accident incidence while just over one-tenth (14\%) reported high incidence. ${ }^{18}$ Talaat et $\mathrm{al}^{19}$ in 2003 found $35.6 \%$ of HCWs from different types of health care facilities from two governorates in Egypt (Nile Delta and Upper Egypt) were exposed to at least one needle stick injury during the past 3 months with an estimated annual number of 4.9 needle sticks per worker. ${ }^{19}$ Another Egyptian study found that, out of $215 \mathrm{HCWs} 86.5 \%$ was exposed to NSSI, and $68 \%$ was exposed to patients body fluid. ${ }^{14}$

Occupational exposure to percutaneous injuries and NSSIs are a substantial source of infections with blood-borne pathogens among HCWs causing substantial health consequences and psychological stress for them and accounts for almost $40 \%$ of the HCV infections. ${ }^{20}$ WHO estimated that 
of 35 million HCWs worldwide, $\sim 3$ million experienced percutaneous injuries each year, and of those injured 15,000 were likely to be infected with $\mathrm{HCV}^{21}$ As stated before, the current work was done at a university hospital where an infection control program was recently implemented with the compliance of the $\mathrm{HCW}$ to practice infection control standard precautions which was still unsatisfactory. Infection prevention and control campaign is mandatory toward raising awareness of HCW about risks, post-exposure management, and prophylaxis during their everyday activity, being the mainstay to ensure their strict adherence with preventive behaviors, including safe procedures for using and disposing of sharps, and banning recapping via constant surveillance, monitoring response, and follow-up. ${ }^{6}$

Serological and molecular assay methods for diagnosing $\mathrm{HCV}$ infection should be helpful to help reduce the burden of this infection. ${ }^{22}$ Serum Ab ELISA has undergone some modifications over decades, seeking to improve their diagnostic capability and increasing sensitivity and specificity of the assay. Current study revealed specificity of $84.44 \%$ (CI 71.22-92.25) and sensitivity 87.5\% (CI 69-95.66) by Hepanostika HCV Ultra ELISA. Other serum Ab ELISA kits were assessed elsewhere and showed absolute sensitivity (100\%) and a high specificity ranged from $88.1 \%$ to $100 \%)^{23}$

The ELISA results were debated by other researchers since the attained results cannot distinguish between active infection and those who have cleared the virus. This is coupled with absence of an efficient culture system for $\mathrm{HCV}$, denoting the necessity of confirmatory nucleic acid amplification technology techniques. ${ }^{24}$ Others claimed for a lower sensitivity and specificity of serum Ab ELISA, ${ }^{25}$ whereas, studies done in subSaharian Africa displayed high false positive ELISA $\mathrm{Ab}$ results in African populations. ${ }^{26}$ However, ELISA is still a recommended test for screening as it is a cheap and easy test.

One step further on evaluation of OraQuick HCV rapid antibody test, it represented sensitivity of $83.33 \%$ (CI 64.1593.32), specificity of $86.67 \%$ (CI 73.82-93.74). Practically, this test is easy to apply using saliva, an acceptable screening tool even for the public sector with a valuable cost-benefit. Our results were supported by other studies, recommending rapid oral $\mathrm{HCV}$ antibody test in particular in the developing countries, highlighting it as being a modified approach in $\mathrm{HCV}$ diagnosis facilitating the possibility of testing millions of people worldwide. ${ }^{27,28}$

Accurate quantitation and detection of $\mathrm{HCV}$ infection with a lower limit of $5-50 \mathrm{IU} / \mathrm{mL}$ can be obtained by RT real-time HCV PCR in the favor of using a single assay and to eliminate the need for other qualitative and quantitative tests. ${ }^{29,30}$ Evidently, confirmation of both ELISA serum Ab and saliva Ab kit results was got by RT real-time HCV PCR in 24 out of 54 participants, and their viral loads ranged from 39.000 to $131.000 \mathrm{IU} / \mathrm{mL}$. In like manner, other studies mentioned real-time HCV RNA, high sensitivity, simplicity, reproducibility, and wide dynamic range especially, of available cost, make this method to be a suitable approach for monitoring viral load during therapy and tailoring of treatment schedules accordingly. ${ }^{31}$

To summarize, $\mathrm{HCW}$ at Zagazig University Hospitals are at risk for $\mathrm{HCV}$ infection with estimated prevalence of $34.8 \%$. Lack of compliance to infection prevention and control guidelines are associated cofactors. Serum HCV-Ab detection by Hepanostika HCV Ultra ELISA, is a sensitive and specific serologic assay $84.44 \%$ and $87.5 \%$, respectively, each for diagnosis with correspondent results to that obtained by quantitative real-time PCR. OraQuick HCV rapid antibody test represented a sensitive (83.33\%) and specific (86.67\%) assay. With best concordance with the reference assay, realtime PCR is easy to apply using saliva and an acceptable screening tool even for the public sector with a valuable cost-benefit. Strict implementation of infection control and post exposure preventive measures should be a part of higher system management plan in all hospital departments.

\section{Recommendations}

Based on the findings from the current study, the authors recommended:

1. Reconstruction of curricula and modification of educational programs to include standard precautions and preventive behaviors to be a habit on daily basis.

2. Knowledge, attitude, and practice to NSSIs of health care beginners should be taken into consideration as a policy statement, being a challenging priority in career objectives.

3. Strict implementation of infection control and post exposure preventive measures should be a part of higher system management plan in all hospital departments.

4. Use of rapid oral test to screen for HCV infection

5. Different health care groups should be included with an appropriate sample size help to attain risk assessment.

\section{Limitations of this study}

The participants obtained by using a convenient sampling technique may not be representative of all hospital departments and limit the generalization of the study results 


\section{Acknowledgments}

The authors are grateful to the participating health care workers for their willing cooperation. This study was funded by the authors themselves with no external support.

\section{Disclosure}

The authors report no conflicts of interest in this work.

\section{References}

1. Abdelwahab SF, Hashem M, Galal I, et al. Incidence of hepatitis $\mathrm{C}$ virus infection among Egyptian healthcare workers at high risk of infection. $J$ Clin Virol. 2013; 57(1):24-28.

2. Breban R, Arafa N, Leroy S, et al. Effect of preventive and curative interventions on hepatitis $C$ virus transmission in Egypt (ANRS 1211): a modeling study. Lancet Glob Health. 2014;2(9):e541-e549.

3. Serdar T, Derek L, Unić A, et al. Occupational exposures in healthcare workers in University Hospital Dubrava - 10 year follow-up study. Cent Eur J Public Health. 2013;21(3):150-154.

4. Frijstein G, Hortensius J, Zaaijer HL. Needle stick injuries and infectious patients in a major academic medical center from 2003 to 2010 . Neth J Med. 2010;69(10):465-468.

5. WHO, Healthcare worker safety. [Cited 2016 November 11]. Available from: http://www.who.int/injection_safety/toolbox/en/AM_HCW_ Safety_EN.pdf. Accessed January19, 2017.

6. Okasha O, Munier A, Delarocque-Astagneau E, et al. Hepatitis C virus infection and risk factors in health-care workers at Ain Shams University Hospitals, Cairo, Egypt. East Mediterr Health J. 2015;21(3):199-212.

7. Pozzetto B, Memmi M, Garraud O, Roblin X, Berthelot P. Health careassociated hepatitis C virus infection. WJG. 2014;20(46): 17265-17278.

8. National Institutes of Health. NIH. Consensus Statement on Management of Hepatitis; c: 2002. Available from: doh.state.fl.us/disease_ctrl/ aids/hep/hepatitis_c_consensus.pdf. Accessed December 22, 2016.

9. Verónica S, Victoria G, Ramon P, Lurdes M, Vicente A, Elisa M. Tools for the diagnosis of hepatitis $\mathrm{C}$ virus infection and hepatic fibrosis staging. World J Gastroenterol. 2014;20(13):3431-3442

10. Lavanchy D. Evolving epidemiology of hepatitis C virus. Clin Microbiol Infect. 2011;17(2):107-115.

11. De Carli G, Abiteboul D, Puro V. The importance of implementing safe sharps practices in the laboratory setting in Europe. Biochem Med (Zagreb). 2014;24(1):45-56.

12. Abdelwahab S, Rewisha E, Hashem M, et al. Risk factors for hepatitis $C$ virus infection among Egyptian healthcare workers in a national liver diseases referral centre. Trans R Soc Trop Med Hyg. 2012;106(2):98-103.

13. Munier A, Marzouk D, Abravanel F, El-Daly M, Taylor S. Frequent transient hepatitis $\mathrm{c}$ viremia without sero conversion among healthcare workers in Cairo, Egypt. PLoS One. 2013;8(2):e57835.

14. El-Melligy DM, Saad-Hussein A, Khalil SA. Occupational exposure to hepatitis infection among Egyptian healthcare workers and hepatitis B vaccination. J Arab Soc Med Res. 2016;11:14-21.

15. Zayet HH, Ezz El-Din AM, Ahmed SM, El-Khayat MR. Hepatitis B and $\mathrm{C}$ virus infection among health care workers in general surgery department, Assiut University Hospitals. Egyptian J Occup Med. 2015;39(1): 85-104.
16. Eskandarani HA, Kehrer M, Christensen PB. No transmission of bloodborne viruses among hospital staff despite frequent blood exposure. Dan Med J. 2014;61(9):A4907.

17. Kebede G, Molla M, Sharma HR. Needle sticks and sharps injuries among health care workers in Gondar city, Ethiopia. Safety Science. 2012;50(4):1093-1097.

18. Vaz K, McGrowder D, Crawford T, Alexander-Lindo RL, Irving R. Prevalence of injuries and reporting of accidents among health care workers at the University Hospital of the West Indies. Int J Occup Med Environ Health. 2010;23(2):133-143.

19. Talaat M, Kandeel A, El-Shoubary W, et al. Occupational exposure to needlestick injuries and hepatitis B vaccination coverage among health care workers in Egypt. Am J Infect Control. 2003;31(8):469-474

20. Centers for Disease Control and Prevention. CDC. The STOP STICKS campaign: sharps injuries. 2013. Available from: http://www.cdc.gov/ niosh/stopsticks/sharpsinjuries. Accessed May 15, 2016.

21. WHO. Aide-Memoire for a strategy to protect health workers from infection with blood borne viruses. Department of Blood Safety and Clinical Technology, Geneva, Switzerland; 2003. Available from: http://www.who.int/injection_safety/toolbox/en/AM_HCW_Safety_ EN.pdf22.11.11. Accessed June19, 2016.

22. Villar LM, Cruz HM, Barbosa JR, Bezerra CS, Portilho MM, Scalioni. Update on hepatitis B and C virus diagnosis. World J Virol. 2015;4(4): 323-342.

23. Maity S, Nandi S, Biswas S, Sadhukhan SK, Saha MK. Performance and diagnostic usefulness of commercially available enzyme linked immunosorbent assay and rapid kits for detection of HIV, HBV and HCV in India. Virol J. 2012;9:290.

24. Swellam M, Mahmoud M, Ali A. Diagnosis of hepatitis C virus infection by enzyme-linked immunosorbent assay and reverse transcriptasenested polymerase chain reaction: a comparative evaluation. IUBMB Life. 2011;63(6):430-434.

25. Irshad M, Dhar I, Khushboo, Singh S, Kapoor S. Comparison of serological and nucleic acid based assays used to diagnose hepatitis $\mathrm{C}$ virus (HCV) infection in acute and chronic liver diseases. Int $J$ Health Sci (Qassim). 2007;1(1):3-10.

26. Mullis CE, Laeyendecker O, Reynolds SJ, et al. High frequency of false-positive hepatitis $\mathrm{C}$ virus enzyme-linked immunosorbent assay in Rakai, Ugand. Clin Infect Dis. 2013;57(12):1747-1750.

27. Smith BD, Drobeniuc J, Jewett A, et al. Evaluation of three rapid screening assays for detection of antibodies to hepatitis $\mathrm{C}$ virus. $J$ Infect Dis. 2011;204(6):825-831.

28. Parisi MR, Soldini L, Vidoni G, et al. Point-of-care testing for HCV infection: recent advances and implications for alternative screening. New Microbiol. 2014;37(4):449-457.

29. Daniel HD, Grant PR, Garson JA, Tedder RS, Chandy GM, Abraham P. Quantitation of hepatitis $\mathrm{C}$ virus using an in-house real-time reverse transcriptase polymerase chain reaction in plasma samples. Diagn Microbiol Infect Dis. 2008;61(4):415-420.

30. Caliendo AM, Valsamakis A, Zhou Y, et al. Multilaboratory comparison of hepatitis C virus viral load assays. J Clin Microbiol. 2006;44(5): $1726-1732$.

31. Shahzamani K, Merat S, Rezvan H, et al. Development of a low-cost real-time reverse transcriptase-polymerase chain reaction technique for the detection and quantification of hepatitis $\mathrm{C}$ viral load. Clin Chem Lab Med. 2010;48(6):777-784.
Infection and Drug Resistance

\section{Publish your work in this journal}

Infection and Drug Resistance is an international, peer-reviewed openaccess journal that focuses on the optimal treatment of infection (bacterial, fungal and viral) and the development and institution of preventive strategies to minimize the development and spread of resistance. The journal is specifically concerned with the epidemiology of antibiotic

\section{Dovepress}

resistance and the mechanisms of resistance development and diffusion in both hospitals and the community. The manuscript management system is completely online and includes a very quick and fair peerreview system, which is all easy to use. Visit http://www.dovepress.com/ testimonials.php to read real quotes from published authors. 